\title{
Pengaruh E-Service dan Kualitas Sistem terhadap Kepuasan Pengguna Sistem E-Learning dengan Moderasi Perceived Value
}

\author{
Shafira Jingga Hernita \\ firajingga@gmail.com \\ UIN Raden Intan Lampung \\ Wahyudin Sidik \\ wahyudinsidik17@gmail.com \\ UIN Raden Intan Lampung \\ Vicky F Sanjaya \\ vicky@radenintan.ac.id \\ UIN Raden Intan Lampung
}

\begin{abstract}
Abstrak
Perubahan kebutuhan dimasa modern menjadikan lembaga dan instansi konvensional berkembang untuk ikut menyediakan layanan daring, salah satunya pada bidang pendidikan. Tujuan dari penelitian ini adalah menganalisis e-service, kualitas sistem, perceived value dan esatisfaction pada pengguna e-learning. Penelitian ini dilakukan dengan menyebarkan 125 kuesioner kepada pengguna aktif e-learning dan terdapat 100 kuesioner yang digunakan. Pengujian dilakukan dengan bantuan alat statistik berupa Structuran Equation Modelling (SEM) berbasi Partial Least Square versi 3 dengan memperhatikan nilai nilai factor loading sebesar $\geq 0,6$, composite reliability dengan nilai $\geq 0,7$ dan nilai variance extracted $\geq 0,50$. Hasil penelitian menunjukkan bahwa e-service berpengaruh positif signifikan terhadap e-satisfaction dengan moderasi perceived value, sedangkan kualitas sistem tidak berpengaruh terhadap e-satisfaction pengguna e-learning.
\end{abstract}

Kata kunci : e-service, kualitas sistem, e-learning, perceived value

\section{Pendahuluan}

Dalam dekade terakhir, industri digital di Indonesia berkembang sangat pesat. Hal ini terbukti bahwa masyarakat Indonesia telah mencapai 175 juta yang aktif menggunakan internet pada bulan Maret 2020 berdasarkan data dari We Are Social. Informasi dan media edukasi pada masa modern ini merupakan hal penting dan menjadi kebutuhan masyarakat, sehingga menjadi tantangan tersendiri bagi penyedia jasa edukasi dan informasi yang ada di Indonesia. Terutama ketika terjadi pandemik pada tahun 2020, protokol kesehatan dari pemerintah membuat situs dan aplikasi belajar secara daring semakin banyak diminati sehingga kursus atau bimbel online pun semakin menjamur. Oleh karena itu, penting adanya evaluasi dari metode pembelajaran elearning karena e-learning merupakan hal yang banyak ditawarkan oleh lembaga pelatihan maupun universitas yang mengharapkan dengan pemakaian e-learning bisa memberikan layanan pendidikan yang terbaik bagi penggunanya (Utami, Arthana, \& Darmawiguna, 2020)

(Sastika, 2018) mengemukakan e-service merupakan model kualitas jasa online yang sangat integratif dan komprehensif sehingga secara menyeluruh relavan dalam pemenuhan kebutuhan jasa elektronik. Maka penulis memilih variabel e-service terhadap e-satisfaction pengguna sistem e-learning untuk melanjutkan penelitian dari (Tobagus, 2018) yang menyatakan bahwa dibutuhkan penelitian lanjutan mengenai e-service dan e-satisfaction yang tidak hanya berfokus pada sektor e-commerce, tapi juga pada bidang yang berbasis teknologi lainnya.

Berbeda dengan produk tangible yang bisa diukur dari kualitas produk dengan mempertimbangkan kemampuan suatu produk untuk melaksanakan fungsinya seperti daya tahan keandalan, ketepatan kemudahan operasi dan perbaikan, serta atribut bernilai lainnya, sedangkan (S.K, Purwanto \& Pawirosumarto, 2016) mengatakan kualitas sistem merupakan 
hasil pengukuran proses sistem informasi yang fokusnya berada pada hasil interaksi antara sistem dan pengguna, yang meliputi seperti ketersediaan peralatan, reliabilitas peralatan, kemudahan untuk digunakan, dan waktu respon sebuah sistem informasi digunakan atau tidak digunakan. Dengan demikian tingkat penggunaan kualitas sistem e-learning yang lebih baik dapat membuat pelaku akademik lebih termotivasi untuk menggunakan sistem e-learning. (Maryana, Ridhawati, \& Sayekti, 2018) di dalam penelitiannya menyarankan penambahan variabel lain yang dapet mempengaruhi e-satisfaction pengguna seperti efektifitas penggunaan serta memperbesar jumlah sampel penelitian. Berdasarkan pendapat (Tulodo, 2019) bahwa kualitas sistem dapat diukur dari sisi kecepatan akses, kehandalan sistem, kemudahan dan keefektifitasan untuk digunakan, kemudahan untuk diakses, dan keamanan sistem. Oleh karena itu penulis memilih variabel kualitas sistem untuk di analisis apakah kualitas sistem juga berpengaruh terhadap e-satisfaction pengguna sistem e-learning.

Kesesuaian kualitas yang diharapkan akan memberikan kepuasan kepada pengguna karena effort atau usaha yang harus dikeluarkan sesuai dengan manfaat yang diterima (Ansyari, Kusasi, \& Iranita, 2019). Serta perasaan mendapatkan nilai terhadap penggunaan suatu produk akan meningkatkan satisfaction (Yuliansyah \& Handoko, 2019). (Rohwiyati \& Praptiestrini, 2020) mengatakan bahwa benar layanan yang berkualitas akan meningkatkan kepuasan konsumen, namun muncul ketidakkonsistenan antara kualitas pelayanan pada kepuasan dengan hadirnya perceived value. Selanjutnya gap lainnya adalah dibutuhkan penggunaan variabel $\mathrm{X}, \mathrm{Y}$ dan $\mathrm{Z}$ untuk penelitian e-service quality terhadap e-satisfaction pada produk tangible maupun intangible (Haria \& Mulyandi, 2019). Maka penulis tertarik membahas pengaruh moderasi perceived value terhadap e-satisfaction pengguna sistem e-learning.

\section{Tinjauan Pustaka}

E-service quality didefinisikan sebagai sejauh mana sebuah situs web memfasilitasi penggunaan sesuatu secara efisien dan efektif. Semakin baik e-service maka akan meningkatkan e-satisfaction. Hal ini didukung oleh penelitian dari (Tobagus, 2018) bahwa hubungan antara eservice quality dengan e-satisfaction dikatakan juga memiliki hubungan yang searah hal ini dapat dilihat pada nilai koefisien arah regresi adalah positif, yang juga senada dengan penelitian (Ansyari et al., 2019) bahwa pengujian secara parsial membuktikan bahwa kualitas layanan berpengaruh signifikan terhadap kepuasan konsumen. (David, 2018) juga mengungkapkan bahwa e-service quality berpengaruh positif dan signifikan terhadap kepuasan pelanggan, semakin baik eservice quality yang diberikan perusahaan kepada pelanggan maka tingkat kepuasan pelanggan akan semakin tinggi.

Namun, (Berlianto, 2017) mengatakan bahwa kualitas e-service yang terdiri dari 5 dimensi yaitu kemudahan penggunaan, e-scape, keandalan, kustomisasi dan jaminan tidak berpengaruh positif terhadap e-satisfaction. Memang tidak semua sektor e-commerce mengutamakan e-service, tetapi terbukti bahwa variabel eservice quality berpengaruh signifikan terhadap e-satisfaction pada produk jasa atau intangible product (Haria \& Mulyandi, 2019). Pada pengujian yang dilakukan oleh (Melinda, 2017) menunjukkan bahwa variabel eservice quality memiliki pengaruh positif terhadap e-satisfaction, karena nilai $\mathrm{T}$ statistik sebesar 10.610 yang berarti lebih besar dari 1.96. E-Service quality pada suatu website memiliki pengaruh yang signifikan terhadap customer satisfaction, karena pengalaman pelanggan menggunakan website dalam melakukan transaksi membuat pelanggan secara langsung dapat merasakan baik buruknya e-service quality (Marlius, 2018).

$\mathbf{H}_{\mathbf{1}}$ : E-Service berpengaruh positif signifikan terhadap e-satisfaction

Kualitas sistem adalah pengukuran proses sistem informasi yang berfokus pada hasil interaksi antara pengguna dan sistem. Kualitas sistem dapat diukur dengan melihat bagian fungsionalnya yaitu usability. Maka tentu saja kualitas sistem ini akan sangat berpengaruh terhadap e-satisfaction pengguna yang berbasis online. Variabel tangible, reliability, responsibility, assurance, dan emphaty secara parsial berpengaruh signifikan terhadap kepuasan mahasiswa pada website akademik (Marlius, 2018). Hal ini didukung oleh penelitian (S.K, Purwanto \& Pawirosumarto, 2016) bahwa semakin baik persepsi kualitas sistem akan semakin meningkatkan kepuasan pengguna sistem e-learning. Hasil pengujian yang dilakukan 
oleh Prawiranata dan Diana (Prawiranta \& Diana, 2018) juga diperoleh nilai r square (r2 ) sebesar 0,676, yang berarti bahwa 67,6\% Kepuasan Pelanggan dipengaruhi Kualitas Sistem Informasi

Namun dibeberapa hal seperti pada Aplikasi Pelayanan Pelanggan Terpusat (AP2T), kualitas sistem tidak berpengaruh secara parsial terhadap kepuasan pengguna (Maryana et al., 2018). Hal serupa juga dinyatakan oleh (Tulodo, 2019) bahwa kualitas sistem tidak berpengaruh terhadap kepuasan pengguna. Tentu saja hal ini bertentangan dengan penelitian yang lain, karena seperti pada kualitas sistem perpajakan di Indonesia,kualitas sistem berpengaruh signifikan terhadap Kepuasan Pengguna E-filling, sehingga semakin berkualitasnya sistem maka akan semakin besar pula kepuasan pengguna sistem tersebut (Putri \& Tambun, 2018).

$\mathbf{H}_{2}$ : Kualitas sistem berpengaruh positif signifikan terhadap e-satisfaction.

Perceived value adalah perbedaan antara penilaian prospektif manfaat apa yang diterima dan biaya yang dikeluarkan oleh konsumen terhadap suatu produk. Perbedaan prospektif ini tentu akan menjadi faktor yang memperkuat atau memperlemah hubungan e-service dan kualitas sistem terhadap e-satisfaction. Hal ini didukung oeh penelitian terdahulu bahwa perasaan mendapatklan nilai atas produk akan sangat berpengaruh dan signifikan (Tri Nawarini, 2019). Penelitian dari (Tulodo, 2019) juga menunjukkan bahwa perceived usefulness berpengaruh terhadap kepuasan pengguna, begitu pula pada penelitian (Yuliansyah \& Handoko, 2019) yang menunjukkan hasil sama mempengaruhi. Berdasarkan hasil pengujian yang telah dilakukan oleh (Ansyari et al., 2019) diperoleh nilai t hitung untuk variabel perceived value 2.463 dengan hasil sig. 0,021<0,05 sehingga dapat disimpulkan bahwa perceived value berpengaruh signifikan terhadap kepuasan konsumen.

$\mathbf{H}_{3}$ : Perceived Value memoderasi e-service terhadap e-satisfaction.

$\mathbf{H}_{4}$ : Perceived Value memoderasi kualitas sistem terhadap e-satisfaction

\section{Kerangka Konseptual}

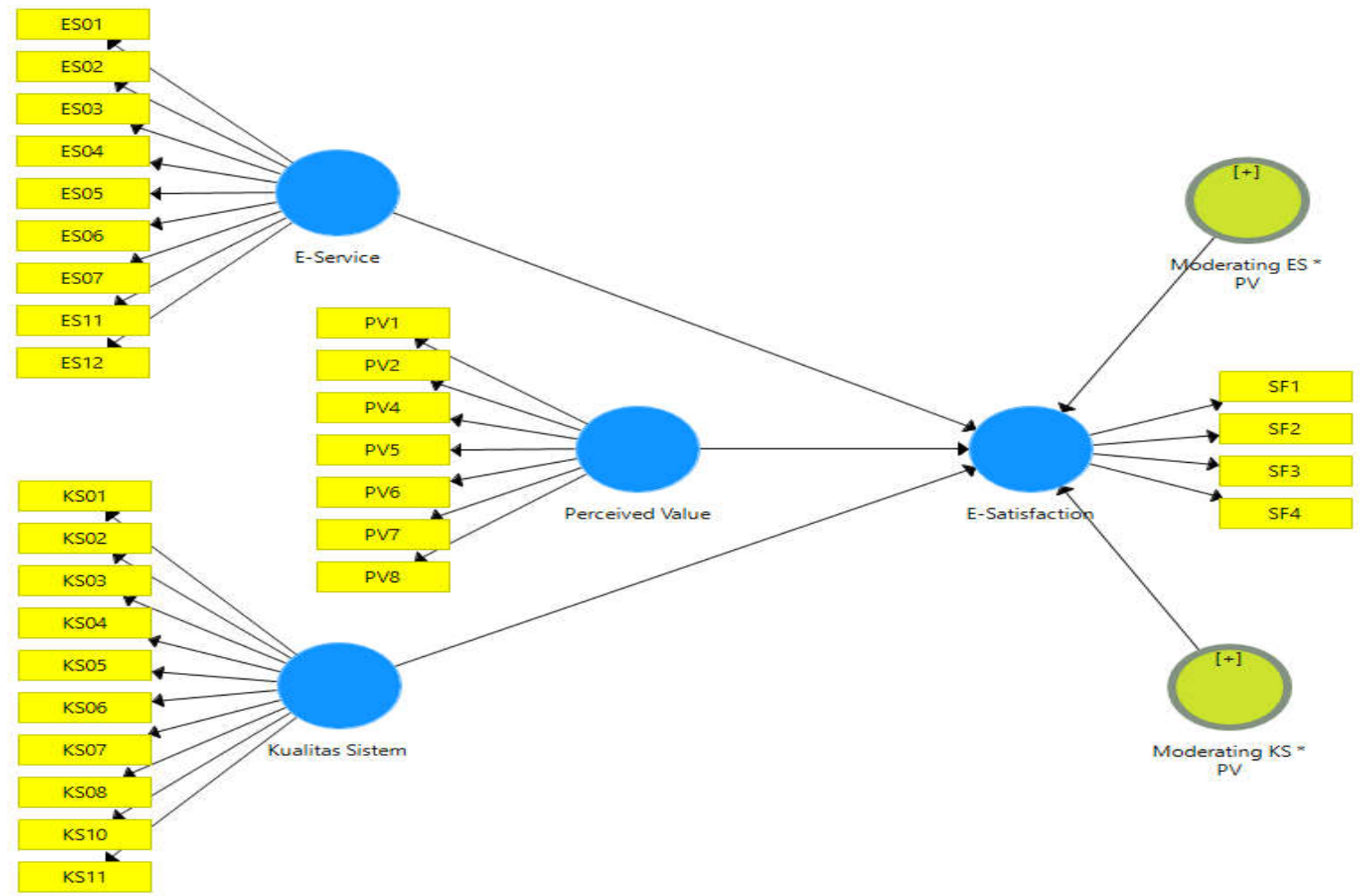

Gambar 1. Model Penelitian 


\section{Metodologi Penelitian}

Peneliti menggunakan metode pendekatan secara kuantitatif dalam penelitian ini. Metode kuantitatif adalah metode yang digunakan pada pada populasi atau sample tertentu, pengumpulan data menggunakan instrument penelitian, analisis data bersifat kuantitatif dengan tujuan untuk menguji hipotesis yang telah ditetapkan (Sugiyono, 2012). Penelitian ini menggunakan bantuan instrumen kuesioner yang dilakukan secara crossectional atau pada satu waktu tertentu. Adapun skala yang digunakan adalah skala likert yaitu ukuran skala penilaian secara berjenjang. Teknik sampel yang digunakan adalah purposive sampling yang melakukan penelitian terhadap sekelompok subjek dengan cicri-ciri tertentu atau dipandang bersangkutan erat terhadap ciri-ciri populasi yang diketahui sebelumnya. Adapun responden dalam penelitian ini sebanyak 100 orang yang pernah merasakan pengalaman belajar atau mengajar secara daring baik melalui suatu situs maupun sebuah aplikasi.

Pengujian statistik dalam penelitian ini dilakukan dengan bantuan alat Statistik Structuran Equation Modelling (SEM) berbasis Partial Least Square versi 3. Uji validitas digunakan untuk mengukur sah atau tidaknya item indukator dalam sebuah kuesioner. Uji validitas dalam penelitian ini menggunakan convergent validity dengan melihat nilai minimum indikator factor loading masing-masing item indikator $\geq 0,6$ (Sarwono, 2006).

Pengujian reliabilitas selanjutnya dengan melihat nilai Cronbach's Alpha dan nilai Composite Reliability yang digunakan untuk mengukur konsistensi internal dalam uji reliabilitas data, serta nilai AVE (Average Variance Extracted) sebagai rerata persentase skor varian yang diekstrasi dari seperangkat variabel laten yang diestimasi melalui loading standardize. Untuk pengujian ini juga peneliti akan menggunakan batasan nilai Composite Reliability $>0,7$ dan Cronbach's Alpha > 0,6 (Sarwono, 2006), serta nilai AVE > 0,5 yang bisa juga dihitung dengan rumus:

$$
\operatorname{AVE}=\frac{\sum_{i=1}^{n} i^{2}}{n}
$$

\section{Analisis Data dan Pembahasan}

Pengujian inner model atau model struktural dilakukan untuk melihat hubungan antara variabel, nilai signifikansi dan $R$-square dari model penelitian. Model struktural dievaluasi dengan menggunakan $R$-square untuk variabel dependen, uji t serta signifikansi dari koefisien parameter jalur struktural.

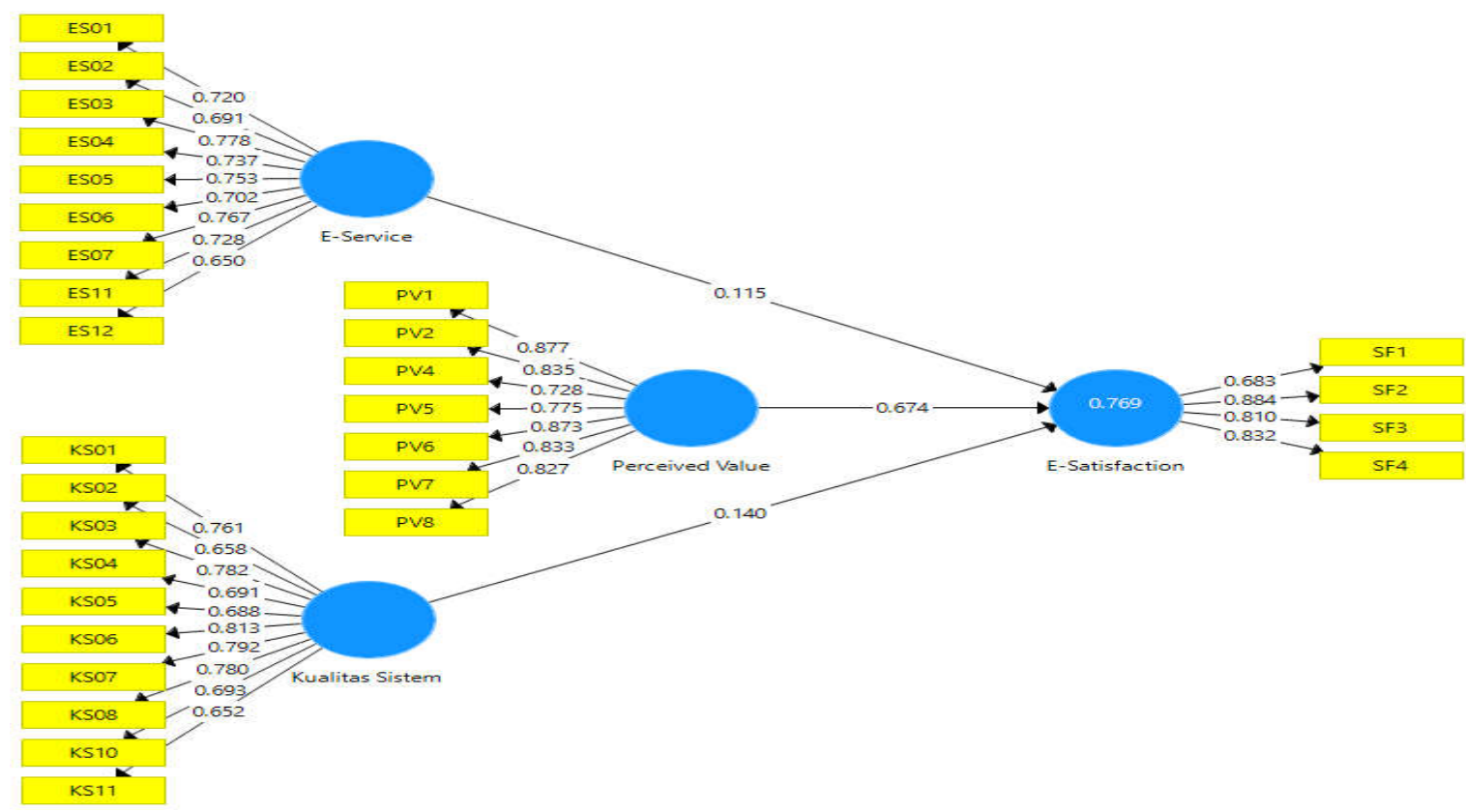

Gambar 2. Hasil Uji Validitas dan Reliabilitas 
Berdasarkan hasil uji validitas dan reliabilitas yang dilakukan menghasilkan beberapa item kuesioner yang gugur karena tidak memebuhi batas standar factor loading. Pada Konstruk E-Service (ES) dari 12 item tersisa 9 item. Kemudian pada konstruk Kualitas Sistem dan Perceive Valued (PV) gugur 1 item dari masing-masing 11 dan 8 item. Sedangkan konstruk E-Satisfaction (SF) tidak ada item yang gugur. Selanjunya dilakukan pengujian ulang sehingga semua item tersebut valid dengan uji validitas memiliki nilai di atas > 0.6 [20].

\section{Tabel 1. Hasil Uji Validitas dengan SmartPLS}

\begin{tabular}{|l|l|}
\hline \multicolumn{2}{|c|}{ Uji Validitas } \\
\hline Item Indikator & Factor Loading \\
\hline ES01 & 0,720 \\
\hline ES02 & 0,691 \\
\hline ES03 & 0,778 \\
\hline ES04 & 0,737 \\
\hline ES05 & 0,753 \\
\hline ES06 & 0,702 \\
\hline ES07 & 0,767 \\
\hline ES11 & 0,783 \\
\hline ES12 & 0,650 \\
\hline KS01 & 0,761 \\
\hline KS02 & 0,658 \\
\hline KS03 & 0,782 \\
\hline KS04 & 0,691 \\
\hline KS05 & 0,688 \\
\hline KS06 & 0,813 \\
\hline KS07 & 0,792 \\
\hline KS08 & 0,780 \\
\hline KS10 & 0,693 \\
\hline KS11 & 0,652 \\
\hline PV1 & 0,877 \\
\hline PV2 & 0,835 \\
\hline PV4 & 0,728 \\
\hline PV5 & 0,775 \\
\hline PV6 & 0,875 \\
\hline PV7 & 0,833 \\
\hline PV8 & 0,827 \\
\hline SF1 & 0,683 \\
\hline SF2 & 0,884 \\
\hline SF3 & 0,810 \\
\hline SF4 & 0,832 \\
\hline
\end{tabular}

Pengujian reliabilitas harus memiliki nilai cronbach's alpha $>0,6$, nilai Composite reliability $>$ 0,7 dan nilai AVE > 0,5 sehingga memenuhi syarat untuk dilakukan pengujian hipotesis.

Tabel 2. Hasil Uji Reabilitas dengan SmartPLS

\begin{tabular}{|l|l|l|l|}
\hline \multicolumn{3}{|c|}{ Uji Reliabilitas } \\
\hline Variabel & Cronbach's Alpha & Composite Reliability & Average Variance Extracted (AVE) \\
\hline E-Service & 0,888 & 0,909 & 0,527 \\
\hline Kualitas Sistem & 0,903 & 0,920 & 0,538 \\
\hline Perceived Value & 0,920 & 0,936 & 0,676 \\
\hline E-Satisfaction & 0,818 & 0,880 & 0,649 \\
\hline
\end{tabular}

1) Analisis pengaruh e-service terhadap e-satisfaction

Berdasarkan hasil pengujian yang telah dilakukan didapatkan hasil bahwa e-service berpengaruh positif signifikan terhadap e-satisfaction dengan nilai $p$-value $0,043(<0,05)$ dan $t$ hitung sebesar 2,025 lebih besar dari t tabel. Maka dapat disimpulkan bahwa hipotesis 1 didukung. Hasil tersebut senada dengan penelitian (David, 2018) yang menyatakan bahwa semakin baik eservice quality yang diberikan suatu perusahaan, maka kepuasan yang dirasakan juga akan semakin tinggi. 
2) Analisis pengaruh kualitas sistem terhadap e-satisfaction

Berdasarkan hasil pengujian yang telah dilakukan didapatkan hasil bahwa kualitas sistem tidak berpengaruh terhadap e-satisfaction dengan nilai $p$-value $0,429(>0,05)$ dan t hitung sebesar 0,791 lebih kecil dari t tabel. Maka dapat disimpulkan bahwa hipotesis 2 tidak didukung. Hasil tersebut mendukung penelitian terdahulu yang dilakukan oleh (Maryana et al., 2018) dan (Tulodo, 2019) bahwa kualitas sistem tidak berpengaruh terhadap kepuasan pengguna. Hal ini bisa terjadi karena kualitas sistem yang dihasilkan oleh situs atau aplikasi e-learning tidak sesuai dengan kebutuhan dan keinginan pengguna.

Tabel 3. Hasil Uji Hipotesis Moderating Effect pada SmartPLS

\begin{tabular}{|c|c|c|c|c|c|}
\hline & Onginal Sample (0) & Sample Mean (M) & Standard Devistion (STDEV) & TStatistics (O/STDEV) & PValues \\
\hline ESenice e) ESStstifaction & 0.179 & 0.178 & 0.028 & 2.025 & 0.043 \\
\hline Kualitas Sistem $\gg$ ESSotisfation & 0.078 & 0.080 & 0.098 & 0.791 & 0.429 \\
\hline Moderating ES'PV $\rightarrow$ ESStifsaction & 0.156 & 0.160 & 0.078 & 1,992 & 0.047 \\
\hline Modertating IS'PV $\rightarrow$ ESSatisfaction & .0 .135 & $-0,144$ & 0.072 & 1.864 & 0.063 \\
\hline Perceived Value $\rightarrow$ - E-Stitsiaction & 0.697 & 0.706 & 0.090 & 7,749 & 0.000 \\
\hline
\end{tabular}

3) Analisis perceived value sebagai variabel moderasi

Berdasarkan hasil pengujian yang telah dilakukan didapatkan hasil bahwa perceived value berpengaruh positif signifikan terhadap e-satisfaction dengan nilai p-value $0,000(<0,05)$ dan t hitung sebesar 7,749 lebih besar dari t tabel, sehingga memenuhi syarat untuk dilakukan uji moderating effect terhadap e-satisaction.

Uji moderating effect perceived value terhadap e-satisfaction dengan variabel independen e-service mendapatkan nilai p-value 0,047 dan t hitung sebesar 7,749 lebih besar dari t tabel. Maka dapat disimpulkan bahwa Hipotesis 3 didukung, yaitu variabel perceived value memperlemah hubungan e-service terhadap e-satisfaction.

Berdasarkan kaidah (Baron \& Kenny, 1986), uji moderasi hanya bisa dilakukan jika efek utama (hubungan langsung variabel independen terhadap dependen) adalah signifikan. Maka uji moderating effect perceived value terhadap e-satisfaction dengan variabel independen kualitas sistem tidak sah dilakukan karena kualitas sistem tidak bepengaruh terhadap e-satisfaction, sehingga hipotesis 4 tidak didukung.

\begin{tabular}{|c|c|c|}
\multicolumn{3}{|c|}{ Tabel 4. Hasil Hipotesis } \\
\hline No & Item & Hasil \\
\hline 1 & Hipotesis 1 & Terdukung \\
\hline 2 & Hipotesis 2 & Tidak Terdukung \\
\hline 3 & Hipotesis 3 & Terdukung \\
\hline 4 & Hipotesis 4 & Tidak Terdukung \\
\hline
\end{tabular}

\section{Kesimpulan dan Rekomendasi}

Berdasarkan hasil uji validitas, uji reliabilitas, uji hipotesis dan moderating effect didapatkan bahwa variabel independen E-Service berpengaruh positif signifikan terhadap ESatisaction pada pengguna e-learning karena p-value $(0,043<0,050)$. Sedangkan variabel independen Kualitas Sistem tidak berpengaruh terhadap E-Satisfaction pada pengguna elearning karena p-value $(0,429>0,05)$. Serta variabel moderasi Perceived Value memperlemah hubungan e-service terhadap e-satisfaction pada pengguna e-learning karena nilai p-value yang mulanya 0,043 meningkat menjadi 0,047. Namun, uji moderasi perceived value dalam hubungan kualitas terhadap e-satisfaction pengguna e-learning tidak dapat dilakukan karena hasil uji hubungan langsung variabel kualitas sistem tidak berpengaruh terhadap e-satisfaction. 
Berdasarkan hasil analisis yang dilakukan, maka penulis memberikan beberapa saran yang dapat dikemukakan dalam penelitian ini adalah sebagai berikut :

1. Lembaga atau instansi yang mengandalkan cara belajar secara online (e-learning) diharapkan dapat meningkatkan e-service untuk meningkatkan e-satisfaction penggunanya, serta tetap memperhatikan perceived value karena apabila e-service tidak memenuhi tingkat perceived value maka akan memperlemah e-satisfaction pengguna elearning.

2. Dalam penelitian ini, penulis hanya melakukan penelitian pada perspektif pengguna aktif e-learning. Sehingga penelitian selanjutnya disarankan melakukan penelitian dari perpektif lembaga atau instansi yang mengelola sistem e-learning.

\section{Daftar Pustaka}

Ansyari, Kusasi, \& Iranita. (2019). Pengaruh Lokasi, Cita Rasa, Harga, Perceived Value Dan Kualitas Layanan Terhadap Kepuasan Konsumen Pada Rumah Makan Tanjung Sebauk. 1-18. Retrieved from http://repository.umrah.ac.id/3287/1/Ansyari Idris-150461201020FE.pdf

Baron, R. M., \& Kenny, D. A. (1986). The moderator-mediator variable distinction in social psychological research: Conceptual, strategic, and statistical considerations. Journal of Personality and Social Psychology. https://doi.org/10.1037//0022-3514.51.6.1173

Berlianto, M. P. (2017). Pengaruh Kualitas Layanan-E, Kepuasan-E, Dan Kepercayaan-E Terhadap Kesetiaan-E Pada Gojek. Business Management Journal, 13(1). https://doi.org/10.30813/bmj.v13i1.247

David, D. (2018). Pengaruh E-service Quality terhadap Loyalitas Pelanggan melalui Kepuasan Pelanggan pada Transportasi Online Grab. Agora.

Haria, T. T., \& Mulyandi, M. R. (2019). Pengaruh E-Service Quality terhadap E-Satisfaction pada Pengguna Aplikasi Mobile. https://doi.org/10.33510/slki.2019.135-140

Marlius, D. (2018). Pengaruh Dimensi Kualitas Pelayanan Website Akademik Terhadap Kepuasan Mahasiswa STIE“KBP.” Jurnal Ipteks Terapan, 12(2), 116. https://doi.org/10.22216/jit.2018.v12i2.633

Maryana, F., Ridhawati, R., \& Sayekti, T. A. (2018). Pengaruh Kualitas Sistem Dan Kualitas Informasi Terhadap Pengguna Aplikasi Pelayanan Pelangggan Terpusat (AP2T) PT PLN (Persero) Wilayah Kalimantan Tengah Dan Kalimantan Selatan Area Barabai. Dinamika Ekonomi, Jurnal Ekonomi Dan Bisnis.

Melinda. (2017). Pengaruh E-Service Quality Terhadap E-Loyalty Pelanggan Go-Jek Melalui ESatisfaction Pada Kategori Go-Ride. Agora, 5(1), 1.

Prawiranta, H., \& Diana, R. (2018). Pengaruh Kualitas Sistem Informasi, Harga dan Kualitas Pelayanan terhadap Kepuasan Pelanggan pada Jasa Gojek di Kota Yogyakarta. Jurnal Pendidikan Akuntansi.

Putri, N. A., \& Tambun, S. (2018). Pengaruh Kualitas Sistem Perpajakan Dan Sosialisasi Perpajakan Terhadap Kepuasan Pengguna E-Filing Dengan Kepercayaan Terhadap Otoritas Perpajakan Sebagai Variabel Moderating. Media Studi Ekonomi.

Rohwiyati, R., \& Praptiestrini, P. (2020). Peran Perceived Value Dalam Memoderasi Pengaruh Kualitas Pelayanan Terhadap Kepuasan Pelanggan Kuliner Kota Barat Solo. Jurnal Riset Ekonomi Manajemen (REKOMEN), 4(1), 24-33. https://doi.org/10.31002/rn.v4i1.2076

S.K, Purwanto \& Pawirosumarto, S. (2016). Pengaruh Kualitas Sistem, Kualitas Informasi, Dan Kualitas Layanan Terhadap Kepuasan Pengguna Sistem E-Learning. Macromolecules.

Sarwono, J. (2006). Metode Penelitan Kuntitatif dan Kualitatif. Yogyakarta: Graha Ilmu.

Sastika, W. (2018). Analisis Kualitas Layanan dengan Menggunakan E-service Quality untuk Mengetahui Kepuasan Pelanggan Belanja Online Shoppe (Studi Kasus: Pelanggan. Journals.Upi-Yai.Ac.Id. 
Sugiyono. (2012). Metode Penelitian Kuantitatif, Kualitatif dan R \& D.Bandung:Alfabeta. Metode Penelitian Kuantitatif, Kualitatif Dan $R \quad \& \quad$ D.Bandung:Alfabeta. https://doi.org/10.1017/CB09781107415324.004

Tobagus, A. (2018). Pengaruh E-Service Quality Terhadap E-Satisfaction pada Pengguna Situs Tokopedia. AGORA, Jurnal Mahasiswa Manajemen Bisnis.

Tri Nawarini, A. (2019). Pengaruh Perceived Value Dan Kepuasan Pada Loyalitas Pengguna Kartu Seluler Di Kota Purwokerto Dengan Variabel Variety Seeking Sebagai Variabel Moderasi. Jurnal Ekonomi, Bisnis Dan Akuntansi (JEBA).

Tulodo, B. A. R. (2019). Analisis Pengaruh Kualitas Sistem, Kualitas Informasi Dan Perceived Usefulness Terhadap Kepuasan Pengguna Aplikasi Care Dalam Upaya Peningkatan Kinerja Karyawan (Studi Kasus PT. Malacca Trust Wuwungan Insurance, Tbk.). Jurnal Riset Manajemen Sains Indonesia (JRMSI).

Utami, N. W., Arthana, I. K. R., \& Darmawiguna, I. G. M. (2020). Evaluasi Usability Pada ELearning Universitas Pendidikan Ganesha Dengan Metode Usability Testing. Jurnal Nasional $\begin{array}{lllll}\text { Pendidikan Teknik Informatika } & \text { (JANAPATI), }\end{array}$ https://doi.org/10.23887/janapati.v9i1.23663

Yuliansyah, A., \& Handoko, T. D. (2019). Pengaruh Perceived Quality dan Perceived Value terhadap Brand Loyalty melalui Customer Satisfaction J-Klin Beauty Jember. Journal of Economic, Bussines and Accounting (COSTING). https://doi.org/10.31539/costing.v2i2.560 